\title{
Tamara K. Hareven: Reflections on a Life Course ... and a Friendship
}

\author{
Loren D. Marks $(1)$
}

Citation: Marks, Loren D.. 2021.

Tamara K. Hareven: Reflections on a Life Course ... and a Friendship. Genealogy 5: 100. https://doi.org/ 10.3390/genealogy5040100

Received: 29 September 2021 Accepted: 15 November 2021 Published: 19 November 2021

Publisher's Note: MDPI stays neutral with regard to jurisdictional claims in published maps and institutional affiliations.

Copyright: (C) 2021 by the author. Licensee MDPI, Basel, Switzerland. This article is an open access article distributed under the terms and conditions of the Creative Commons Attribution (CC BY) license (https:// creativecommons.org/licenses/by/ $4.0 /)$
School of Family Life, Brigham Young University, 2092C JFSB, Provo, UT 84604, USA; loren_marks@byu.edu

Abstract: Tamara Hareven, as a new social historian and family historian, weaved multiple narratives together into a tapestry that represented her best approximation of truth. In this piece, I strive to do likewise as I address three topics: (a) Tamara Hareven as Family and Social Historian, (b) Tamara Hareven as Theorist, and (c) Personal Reflections on Tamara Hareven as Mentor and Friend.

Keywords: social history; family history; life course; memoriam; Tamara Hareven

It is a privilege to write this piece in honor of the late Tamara Hareven for Genealogy at the invitation of guest editor Professor Barbara Settles, a long-time colleague of Hareven's at the University of Delaware. Settles and I both had the privilege of preparing and delivering "In Memoriam" comments to University of Delaware audiences following Tamara's passing and I am delighted that the intellectual contributions and life of this remarkable soul are being celebrated in a collection of articles two decades after her death in October 2002.

Tamara Hareven sought throughout her career to weave multiple narratives together into a tapestry that represented her best approximation of truth. In this piece, I will strive to do likewise as I address three topics: (a) Tamara Hareven as a Family and Social Historian, (b) Tamara Hareven as a Theorist, and (c) Personal Reflections on Tamara Hareven as a Mentor and Friend.

\section{Tamara Hareven as Family and Social Historian}

Hareven's cross-cultural work in family history covered multiple contexts and countries, including but not limited to New England, China, France, and Japan. Her work yields dualism and complexity. Culture, historical timing, context, and the array of challenges that families live within are widely variegated. For Hareven, the nexus of concern was that within the milieu that time, fate, and circumstances hand us, we co-create our story, our life course, and our family history.

Hareven's rare ability to listen to and then reconvey the life stories and histories of others was recognized both in academic circles and in the popular press. Settles (2003) reflected, "Tamara Hareven ... could tell a good story ... and reach the educated person or student regardless of their background or training". Indeed, she could. In taking some time to examine reviews of her books, I encountered excerpts including the following:

"Perhaps it is that Hareven ... let the mill people speak so freely throughout the work that makes the story so believable ... . Amoskeag is the best of the new social history". (Richmond News-Leader)

"[Hareven] interviewed generations of workers at every level-from owners and executives down to the least skilled". (The New Yorker)

"Workers speak in their own voices, as subjects in their own right". (New York Times Book Review)

The "new social history" Hareven championed offered voice to the overlooked and the marginalized. One colleague referred to her as a "champion of the underdog". In her own words, a vital aim was "a commitment to reconstructing the life patterns of ordinary 
people, ... viewing them as actors as well as subjects in the process of change" $(2000$, p. 3$)$. As I look at my own work that has focused on religious minorities and racial minorities, I see her influence.

Her influence carries into other aspects of my work as well. I have read book-length qualitative studies where researchers have gone on for several pages summarizing participants' comments without offering a single, extensive, direct quotation from a participant. This approach was not Hareven's. When she wrote, Tamara allowed "her people" to speak, literally, in their own language, in their own voices, and in their own idiom. One insightful review of her work captured her focus on honoring her participants' authentic voices particularly well:

No one who has watched a rich and lively interview die between tape recorder and transcript can feel anything less than awe before the taste, skill, and immense labor... which make this book a triumph of selective intelligence in the service of historical truth. (The Nation)

Hareven's passionate commitment to an approach to social and family history that captured and shared the voices and stories of the forgotten, the marginalized, the overlooked, and those without privilege, both illuminated and shined through her work. I continue to see and feel her influence on my own qualitative work on families. A few years ago, I wrote that in interview-based, qualitative research,

The author(s) must determine how much of the findings section will be comprised of participant-voiced data ... and how much will be author-driven commentary and/or summary. Will you be a choir director who blends and harmonizes voices [of others] or will you be unable to resist the temptation to grab the microphone for repeated diva solos? (Marks 2015, p. 503)

Hareven was a remarkable "choir director". Even so, there are times when solos are appropriate and she occasionally enjoyed the spotlight and accepted speaking engagements, including plenary conference addresses and featured talks at universities (including an honorary doctorate from Linkoping University in Sweden). Even so, when these opportunities arose, her comments tended to heavily feature the voices and narratives of the families and persons she had interviewed.

For the genealogist or family historian who delights not only in the "tombstone information" of birth and death dates, but in the narratives behind the dash between those dates, Hareven was your kind of family historian. She wrote, "[W]e need to find a comfortable equilibrium between quantitative analysis and 'thick description.' Too often, quantitative and qualitative methodologies have been presented as mutually exclusive. Analysis of kinship will be served best by merging the two" (2000, p. 18).

In George Eliot's (aka Mary Anne Evans) classic work, viewed by some as the pinnacle of 19th century British literature, Eliot presents a dizzying array of individual characters that are slowly integrated into a coherent social portrait that vibrantly captures both the processes and problems inherent in the specific culture and community of Middlemarch (Eliot 1871). In like manner, especially in Amoskeag (Hareven 1978b) and The Silk Weavers of Kyoto (Hareven 2002), Tamara Hareven accomplishes something of the non-fiction equivalent, but with the added price of needing years of painstaking interviewing, field work, transcription, and study before the writing could truly begin. One reviewer wrote of Hareven's work, "The lives recorded here really do breathe [and] attain, indeed, considerable cumulative impact before the end" (Atlantic Monthly).

A vital intangible a great interviewer and qualitative researcher must have is a countenance and a presence that infuses the interviewee with a desire to tell the unvarnished truth. Having known her well, I have reflected on why so many trusted Hareven enough to allow her to step onto their sacred, personal ground. Why were they willing to be vulnerable enough to share their truth with her? An important insight to answering this question may be found in the closing paragraphs of her career-spanning collection, Families, History, and Social Change (Hareven 2000) where she wrote, 
My exposure to Japan has led to a great transformation in my role as an American historian. The decade during which I conducted comparative research on family and work among the silk weavers in Kyoto exposed me to what de Toqueville described as turning the mirror onto ourselves. Part of my impetus was the conversation I had had with several highly skilled silk weavers in Nishijin (Japan) ... as I asked them certain questions that had emerged from my study of the Amoskeag Mills. The weavers were silent. Finally, one of them asked, "How do you know to ask these questions?". (p. 333)

Perhaps Hareven received so much truth, honesty, and depth ${ }^{1}$ because she had deeply pondered the questions she wanted answered and then pursued those salient queries relentlessly and with tenacity - not through coercion, but through the willingness to listen and to wait for the full personal and family story. As she knew, this could sometimes take hours-or even months. Similarly, Hareven understood that great patience and effort were required to truly comprehend and express a cultural or subcultural story. Some chided her for taking so long to publish her final work, The Silk Weavers of Kyoto (2002). The questioners included her own father, Saul. She wrote,

Trying to understand another culture is a formidable and humbling task. In 1991, when my parents, who lived in Israel, were staying with me in Delaware during the Gulf War, my father asked me, "When are you going to finish your book on Japan?" [Note: It would be another 11 years]. "You have been going back and forth to Japan so many times, and still there is no book". I responded by saying, "Maybe I will never finish this book, because I have to learn so much about Japan, and I need to keep going back there". After some moments of silence, my father turned to my mother and said, "She is right. It takes a long time to understand another culture". Indeed, I am still learning. (p. xvii)

Pearl S. Buck, speaking of her Pulitzer-prize winning novel of rural China, The Good Earth, explained, "I can only write what I know, and I know nothing but China, having always lived there." It seems to me that Hareven intentionally sought to know Amoskeag, then Lyon, then Kyoto and then in due time and not before, she wrote what she had come to know (Buck 1931).

One of the most fascinating "meta-stories" in her prolific body of work is offered to us in Families, History, and Social Change (Hareven 2000) via the person and extended family of Anna Fregau Douville. Hareven sets the table by explaining that

The subordination of individual needs to family decisions did not always take place without conflict. Many interviewees who had made personal sacrifices expressed long-repressed anger and pain during the interview. Anna Fregau Douville, for example, as the last child of working age who could support her parents, left school and started working at age fourteen and [later] postponed her own marriage. When Anna finally announced she was going to be married, her sisters pressured her to cancel her engagement, claiming that her fiancé was a drunkard. Actually, "they [my sisters] were scheming to get me to support my folks until they died .... But my mother told me, 'Anna, don't wait too long ...'." Anna got married and lived two houses away from her parents. Although Anna was determined to live her life independently of her family, she was never quite free of guilt. Having grown up in a large family where she experienced firsthand the pressures imposed by kin, Anna subsequently set strict boundaries with her husband's family immediately following her marriage. She refused to pay her mother-in-law's debts and made it clear to her husband that they could not rely on her to compensate for their extravagances. (p. 60)

Hareven then offers Anna's own words:

I [Anna] put my foot down the first year I got married .... When his parents used to come and visit me and ask to borrow money ... I said, 'Listen, I don't go down to your house to bother you. I'm happy with my husband ... get the hell 
out. Don't ever come here and try to borrow anything from him or from me.' ...

My husband agreed with me. He said, 'I'm glad that you can open up with them.

I couldn't talk that way to my own family'. (pp. 60-61)

However, Anna's strong, devil-may-care portrayal of herself is deepened and contrasted later in the same work. Hareven wrote, "Anna Douville, whose case is described in part in Chapter 2, delayed marriage and then set her own strict household rules to prevent further incursions on her life. But her regrets about her behavior plagued her later on" (p. 98). Tamara then chooses to again feature Anna's own words from later in her interview:

They [my parents] were on the city welfare ... even with the hard times I had during my life, I never stopped for sympathy for myself, because I knew about my mother's life ... . A lot of things go through your head when your folks are gone ... . You don't realize it when they are living. You want to live your own life; but when folks are gone and you think of all the good things that you have today, you wish they could share them. (p. 98)

The award-winning Nigerian novelist Chimamanda Ngozi Adichie has written and spoken at length about what she calls "the danger of a single story". Tamara was well aware of this danger. In her rich and textured portrayal of Anna and her family, we are reminded that even as individuals and families, we do not have a "single story" but many stories. Like Anna, we may vacillate from defensive to vulnerable, from triumphant to regretful. An additional layer of complexity is added by Hareven (that is of particular importance to family historians and genealogists) when she further explains that

Interestingly, despite her resentment of extended family obligations and her own bitterness toward her siblings, Anna Douville kept the most complete family albums and follows the traditional Quebec custom of maintaining a family genealogy. Her personal resentment of the intrusions of kin into her own privacy was divorced from her ideological commitment to keeping a complete family record for posterity. (p. 61)

It seemed that there was always more to the story Hareven wished to share. And yet, publishers have page limitations—setting the stage for several battles I witnessed during my time as her graduate assistant. "A 40-page limit!" she would lament. "I have hacked away to get it to 65, and now they ask this-for me to cut off my right arm. You do it LAH-ren [she could never say Loren], I cannot bear it". She was not without a flair for the overdramatic when it suited her.

My face donned a half-smile, half-grimace when I read in the Acknowledgments section of The Silk Weavers of Kyoto, "Loren Marks has been extremely helpful in his incisive suggestions for the painful but necessary reduction in length ..." (p. xxiii). Even 20 years later, her words read a bit like a recovering patient thanking a surgeon for an amputation through clenched teeth.

A discussion of publishing pragmatics brings us to the seemingly effortless elegance of Hareven's writing style and multilingualism. Wikipedia notes Hareven's familiarity with at least five languages. I believe this estimate to be two to three languages too low, but it is certain that English was far from her mother tongue. After her native Romanian and Hebrew, English was her third, fourth, or fifth language but she was a master of English prose nevertheless.

\section{Tamara Hareven as Theorist}

In addition to being a world-class family historian and exceptional writer, Hareven had a creative and innovative side. She exercised this aspect, in part, by helping to found two journals: Journal of Family History and The History of the Family: An International Quarterly. Her creative side also found expression in conceptualization and theorizing. This led to her development (with sociologist Glen Elder) of the life course perspective (Elder and Hareven 1994) - a conceptual and theoretical lens that has since been employed not only in 
history, but in sociology, psychology, family studies, economics, and other disciplines and fields.

Important concepts and aspects of the life course perspective include careful attention to the interrelationship between "individual time", "family time", and "historical time" (2000, p. 4, emphasis added). In simple terms, psychology has focused on the first and history on the last, but the family - both in its own right and as the bridge between micro- and macro-levels of human life and systems-had been comparatively marginalized until at least the mid-20th century. In the words of her Delaware colleague and friend, emeritus professor Rob Palkovitz, "One of Tamara's most useful contributions to understanding the nuances of timing was her elaborations on how individual time, family time and historical time may complement one another or exert oppositional forces to one another. For example, though it may be the perfect time for an individual to relocate for a promotion (individual time), thinking about uprooting children and placing them in a new school as they finish high school (family time) may prohibit accepting the offered promotion" (Personal communication, 16 August 2021).

Extending the ideas of the influential sociologist W. I. Thomas, Hareven (2000) presented "the family as an active agent" noting that "the family planned, initiated, or resisted change; it did not just respond blindly" to historical and cultural forces (p. 18). A related concept of Hareven's (2000) was that of family strategies. The family, she posited, was "both a custodian of tradition and an agent of change" - and to better understand the role of family in historical processes, we must not only ask how historical forces influenced families but also how families have influenced and actively responded to historical forces (p. 23). Phrased differently, for Hareven, historical and cultural forces did not merely "happen" to families. Many families showed creativity, resourcefulness, cooperation, and synergy in adapting to meet the challenges that came. Some of these strategies failed miserably and most had heavy costs. However, the central point is that "families charted their strategies in relation to external opportunities and constraints", including wars and recessions, economic booms and opportunities, and so forth. "Family strategies involved not only the decisions individuals or families made but also the actual timing of such decisions" given that "strategies were part of a larger life plan" (p. 23). These views have influenced my work across time, including empirical and conceptual treatment of how highly religious families harmonize "firmness and flexibility" and how they creatively frame the "demands and expectations" of their faith communities vis-à-vis the "benefits and blessings" they perceive. In such a view, families are constantly wiggling, negotiating, creatively re-framing, and strategically acting to realize collective goals.

The concepts of family strategies and "life plans" lead us to the life course concept of linked lives. Hareven and Elder's noting of linked lives is an explicit acknowledgement that in spite of the American foci of independence and individual rights, we are inextricably connected by blood, obligation, and expectation to others-and by care, compassion, and empathy. This concept heavily influenced one of the most salient ideas of my own, the principle of lived invitation: "Our behavior is permission to others to behave similarly ... but it is more than that. It is an invitation to do so" (Marks and Dollahite 2017, p. 14). The principle reinforces the notion that our decisions to act (or not to act) have ripple effects that extend well beyond our own lives.

Returning to linked lives, as conceptualized by Hareven, the significant decisions and actions we chart influence others-in both liberating and limiting ways. The decision of one sibling to marry or move out of state may directly lead to another sibling forgoing marriage to care for an aging parent. Indeed, the potency of linked lives is perhaps most apparent during key family and life course transitions, including births, deaths, marriages, graduations, and migrations. Hareven further emphasized that not only were transitions of special import, so was the timing. For example, the timing of the transition to motherhood at 15 might be "early", 25 (or 35) might be "on time", while 45 might be "late").

The concept of transitions was important enough to Hareven that she entitled one of the three books she published in 1978, Transitions: The Family and Life Course in Historical 
Perspective (Hareven 1978a). Her focus on the power of family transitions would never wane and she would carry it into her cross-cultural work in France and Japan. Two decades after the publication of Transitions, Hareven was pleased to learn in Nishijin and Kyoto that the Japanese had a word that combined timing and transitions. She wrote (2000):

In Japan, the term tekerei designates set norms of timing - the ages 'fit' for accomplishing various life transitions .... Tekerei also means the orderly sequence of life transitions. (p. 153)

A final life course concept of Hareven's I will briefly highlight is that of human agency. Just as she spent her career marshalling evidence that many families were "active agents", she did not see individuals as 8-balls on the billiard table of life waiting to be unwittingly smacked about by the cue ball of social forces. Even so, she was poignantly aware of cruel forces outside of personal or familial control. Tamara was born a Romanian Jew and she and her parents, Mirjam and Saul Kern, resiliently wandered in the post-World War II Jewish diaspora through multiple countries (including Palestine). It is telling that near the end of her life, the dedication of her penultimate book reads: "to Mirjam and Saul Kern-Heroes in their own lives".

In spite of challenges, changes, and the Holocaust, Tamara eventually found her way to elite universities where she excelled. In the 1960s, she commenced her ascent and by 1978 she had approached the apex of the then overwhelmingly male-dominated profession of academia in the male-dominated discipline of history.

Hareven had an iron will and did not like to be told 'no' by anyone. She was as determined and (consistent with her own concept of human agency) as self-determined as any person I have ever known. Yet, she was aware that in spite of the staggering challenges she had faced and overcome, she had also enjoyed some rare educational privileges and opportunities that were not and are not available for most persons. Her version of human agency was a contextually sensitive one that called for the fullest possible awareness of the multi-layered milieu in which a family and individual both act and are acted upon. I continue to feel her influence as I study and write about Black families, immigrant families, and religious minority families that have unique strengths but also face steep and sustained climbs up the hill to full opportunity and actualization of their versions of the American dream.

In summary, Tamara's conceptual work as a theorist was much like her work as a family historian in that she almost seamlessly interwove several different threads into a colorful, rich, and coherent whole. The longer one spends considering life course concepts including individual/family/historical time, family strategies, linked lives, transitions, timing (tekerei), and human agency, the more these concepts seem to be woven into a single theoretical tapestry.

\section{Personal Reflections on Tamara Hareven as a Mentor and Friend}

In the final section of this attempt to honor the legacy of Tamara Hareven, I will transition to the deeply personal and relational (please see attending footnote). ${ }^{2}$ Indeed, none of my academic publications approaches the vulnerability of this one, for Tamara or for me. It is my hope that my best effort at sharing my version of the truth-without the varnish or sugarcoating for which she had no patience-will honor her memory and legacy. I believe Tamara would want it that way.

As a newly arrived 27-year-old graduate student at the University of Delaware, one of the first conversations I had with Tamara began with an abrupt query with no warm-up. "LAH-ren, I know you are a Mormon. ${ }^{3}$ Are you a wine-drinking Mormon or are you a non-drinking Mormon?"

"I'm the non-drinking kind", I said.

"Oh", Tamara said, "I have known both kinds and wanted to be clear from the start".

I don't think she was particularly concerned about my level of orthodoxy as a member of my faith, but over the years of our friendship during my doctoral program at the University of Delaware, Tamara generously spent thousands of dollars taking my wife 
Sandra and me to several of the finer dining establishments in the mid-Atlantic at a time when we could hardly afford the McDonald's drive thru. I am pleased that our water over wine teetotaling saved her hundreds of dollars.

Continuing on the note of Tamara's generosity, my own academic administrator at BYU, Erin Kramer Holmes (a graduate student at Delaware concurrent with me) reminded me that our oral final exam for Hareven's class took place in a fine Asian restaurant in Newark, Delaware, where we collectively talked about the learned jewels from the semester while feasting on a dazzling array of Asian cuisine-all at Tamara's expense.

My wife Sandra, who also teaches at BYU, and I have tried to similarly model Tamara's generosity by making the second Sunday dinner of the month, "BYU Student Sunday".

Similarly, Tamara's focus on extracting the most important ideas or jewels from class readings has impacted me in asking my own family studies students to bring their typed "Gems" each day to share with the class in the same open discussion format that Tamara favored.

On another early occasion during my time at Delaware, Tamara said to me, "Tell me about your dissertation topic". My working idea at that point was to address the topic of fathers and faith. I explained this to her briefly.

With her standard directness, she said, "Why only interview men?"

"Because", I responded defensively, "about $90 \%$ of the current parenting studies are based on mothers" reports, while ignoring fathers".

"I see", Tamara said. "So, you are determined to commit this same sexist sampling sin, but in reverse?"

I will only cursorily mention the awkward tension I felt in that moment, and the added frustration I experienced when Sandra later said, "She is right, you know". I will say that when I began conducting the in-depth interviews that would become the foundation of my own academic career, I interviewed mothers and fathers of various faiths. This would prove a pivotal decision for all that would come later, but it was only the beginning of Tamara's mark on me. Never again would my academic work feature only the voices of men. Tamara helped me to see that family history is woefully incomplete without Her Story.

After learning that I wanted to explore the volatile topic of religion and families, Tamara said to me one day, "You are aware that I know Bushman?" (Richard Bushman, the renowned historian, had previously left Delaware to accept an endowed professorship at Columbia University and is now the leading living historian on the foundations of the Church of Jesus Christ of Latter-day Saints and its founder, Joseph Smith).

"No, I was not aware that you know Bushman", I responded. Bushman was (and is) an intellectual and spiritual hero of mine, but I had regrettably never met him.

"Bushman's work on Joseph Smith addressed many difficult topics and it was impeccable, careful, and of the highest quality". She stopped and let her words linger. She then looked at me piercingly, as if to say, "I expect the same from you and you will be a great disappointment to me if you do not make yourself equal to this challenge".

Later that year, in her graduate course on "Life Course and Family", I wrote my term research paper on her life course concept of human agency. Her response comments, handwritten and in black ink, were nearly three pages long. Many of her comments criticized me for my overextension of her concept. She explained in the clearest possible terms that her views of human agency did not extend as far as those of concentration camp survivor and Jewish luminary, Viktor Frankl, who saw the human will as sovereign. Honoring my own agency as she counseled me, she said that even if my personal beliefs aligned with Frankl's to "please be careful" in how I expressed and conveyed those beliefs lest I be "scorned and laughed out of academia". She was part scolder, part mother, and part mentor.

I would soon have the chance to put the concept of human agency to the test. I learned from another mentor, Professor Rob Palkovitz, that for some inexplicable reason, Hareven had taken a shining to me and was going to ask the department chair that I serve as her 
graduate research assistant for the next year or two. Hareven tended to get whatever she requested-a publication record like hers and a steady stream of seven-figure grants tended to garner "Yes" responses to most administrative requests.

Even so, the reality was that no grad student wanted to work with her. Hareven's standards were infamously high, but you still had to meet them. She often needed 30 hours of work per week, but the assistantship paid for only 20. Even so, "yes" was the only acceptable answer. An additional reality was that her staggering native intelligence, her stature in the field, and her productivity, coupled with her bluntness and heavily guarded (even prickly) style of social interaction combined to form a figure that terrified most of the graduate students-and seemed to strain her relations with many colleagues. ${ }^{4}$

I took a weekend to think through what appeared to be my impending doom and talked it through with Sandra. I decided two things by the following Monday: (1) If I was going to be drafted into a war I did not want to fight, I would seize my own fate as an "active agent" and go to Hareven and voluntarily enlist; and (2) I was determined to learn to love this woman that many feared. As I was soon to learn, the volunteering would come far more easily than the love.

I went and courageously (I thought) told Hareven that I would like to serve as her graduate assistant that coming fall. She seemed pleasantly taken back but quickly regrouped and said, "If you wish to work with me, you will start now. I have an edited volume [Note: Family History Revisited, published in 2001 (Wall et al. 2001)] and several papers that need careful editing." My 30-hour weeks (on top of graduate work) would commence almost immediately - and my bold move of choosing my own course began to look foolish, if not downright self-destructive.

To say that Hareven's standards were high would be understated. While calling them pathologically perfectionistic might be too harsh, such a judgement would not be far from the objective truth.

As Barbara Settles has written, Tamara told a very good story. Like many, I was initially struck with the universal appeal of her writing-the seemingly effortless flow and clarity that make her work highly readable and lucid for the seasoned academic and lay reader alike. What a gift! Or so I thought. Tamara's clarity in writing was, as I saw behind scenes, a perpetual exercise in perseverance, craftsmanship, and endurance-not an unending and effortless stream of first-draft excellence. The raw effort required was compounded by the reality that she did not personally use a computer. During the time that I worked for her, I never saw her type a word. Tamara would handwrite each of her first drafts, then give these to her in-office, personal secretary for typing. (She went through many secretaries.) Draft after draft would be edited by me, then be reprinted in hard copy, then (again) be revised heavily by Tamara and her black pen. It is difficult to imagine that someone with hundreds of publications would give such care to each one, but she did. This arduous approach was not helpful to me in my quest to learn to love this indomitable woman.

I came to learn that Tamara was fearful of many things and was easily agitated. She had a personal driver on retainer, not as an elitist statement but because she did not drive. I do not believe her tightly wound constitution could have handled driving alone in heavy East Coast traffic. Bridges, large crowds, and airplanes were also among her fears that reached phobic levels. These latter fears were highly problematic due to her heavy schedule of international travel, often to Lyon, France, or Kyoto, Japan. I was begrudgingly impressed that despite the palpable fear that Tamara manifested, she was repeatedly willing to brave her various terrors for the opportunity to either learn or to teach.

For some reason-Sandra, my wife, hinted that it might be my painfully slow cadence of speech-Tamara seemed to draw some relaxation and comfort from me at these stressful times of travel. Although her driver would typically pick her up from the airport upon her returns, she would often ask me to drive her to her departures (she preferred the Philadelphia airport). I repeatedly considered telling her that I was already working 
multiple unpaid hours for her and that being her graduate assistant did not make me her taxi driver. However, I either lacked the courage or recalled that the last time I tried to demonstrate courage, I ended up with a lot more demands than before.

I do not recall hearing Tamara discuss matters of religion with anyone else, but almost from the outset she did so with me. She was a person of quiet yet profound faith. When her international flights had legs or layovers-or before her return trips to the United States-Tamara would call my landline at home and would ask me to pray for her. Given the time differences, these calls often came between 1:00-4:00 A.M. Sandra, my very patient wife, recently commented, "'I remember a time when Dr. Hareven's calls woke us more often in the middle of the night than our babies did, but she was so good to us". My prayers for Tamara were not to be said at some vague later point, but immediately, during her international call, with her carefully listening to each word. This was not a rote ritual; she was literally asking me to plead with the God of Abraham to give her shalom (peace) as she faced her profound fears connected with travel. As I look back, these moments were sacred ground.

Although she was not an observant Jew in terms of kasherut (she loved seafood and porkchops), I have never seen a person more thoroughly worship on a holy day than Tamara would on Yom Kippur, the Jewish Day of Atonement.

During my time with her, I was reminded by a rabbi that my surname (Marks) is a Jewish name. Tamara was aware of this and one of the rare compliments she paid me was when, with a twinkle in her eye, she suggested that I might be one of the lost Jewish sages of Hebrew folklore, specially sent to help her.

We often discussed literature-she was exceptionally well read-and at one point she asked if I had read Chaim Potok's (1981) The Book of Lights. I told her that I had and that it had stimulated my interest in studying Jewish mystical writings. "LAH-ren, you must re-read it now", she said. Not a recommendation, but an edict. I did so. To summarize a minor but germane plot point of The Book of Lights, the protagonist (Gershon Loran) is a brilliant but lonely Jewish academic who leaves university study to serve as a military chaplain in post-war Korea. His first assistant there is a quiet Mormon boy from Salt Lake City (my own birthplace) named Roger, who dutifully serves Gershon. Roger is full of both innocence and naïveté and is frustratingly simple in his deep faith. Yet, Gershon comes to care for Roger. Potok writes that Gershon eventually felt a "warming sense of security and satisfaction ... whenever he thought of Roger" and Gershon confesses an emptiness when he is parted from Roger. In my experience with her to that point, Tamara was incapable of physically or verbally expressing the emotion of love. Her affection- to borrow another Potok phrase from The Book of Lights-was an "inarticulate love". Even so, the oblique but tender message from Tamara via Potok was not lost on me. It was an important marker in our relationship.

Months passed with a heavy workload and high demands. There were more calls for prayers during the dark hours of night and early morning. There were also many lovely dinners for Sandra and me with Tamara-always at her generous expense.

Sandra and I were blessed with our second child, Logan. Tamara bought him clothing and toys, including a special stuffed animal she brought back from France. Unfortunately, Logan wrestled with lung problems and was hospitalized with pneumonia at nine months. It has been said that there is at least one inherent blessing in experiencing pain. That blessing is that, if we are human in the best sense of the word, it is our pain that enables us to truly feel for others during their times of sorrow. Tamara was no stranger to pain, yet she did not allow the pain she had experienced to embitter her. Instead, she cultivated her pain into a compassion that one can feel in her treatment of persons struggling with life's challenges in much of her work. During this time when our baby was struggling near the edge of life, Sandra and I felt that same compassion in Tamara's daily calls and constant concern and prayers for our son. During those weeks, she made no mention of my work for her that was lagging. Logan lived, despite a second hospitalization four months later. Tamara's concern was again almost excessive. 
Two more years passed, and the completion of my $\mathrm{PhD}$ approached. I began a desperate search for a job and applied to more than 40 universities. My publications numbered only three, and it was apparent that I would need something of a miracle to land the research professorship I desired. Tamara knew this. I was never permitted to read any of the scores of letters of recommendation that she wrote for me but her secretary, Janice Thompson, informed me that Tamara was especially meticulous and lengthy in her efforts on my behalf and once, via a series of faxes from France, wrote five drafts of a single letter of recommendation in order to make it "just right". How many professors would do such a thing for a graduate student? Due in large measure to kind and generous words from Tamara and a later phone-based recommendation from Barbara Settles, I was employed by LSU. The job offer was celebrated over dinner with Tamara who said, "LAH-ren, it will take at least ten years for you to fully comprehend how fortunate you are to have landed a professorship at a research university straight out of your doctoral program with the modest record that you have". She was not one to throw away a compliment.

Twenty years later, I confess that I still wonder what it was that she wrote that helped convince LSU to give a rather simple and unproven scholar an opportunity. I have been tempted to request the letter from those old files, because her approval and opinion mattered deeply to me. However, if she had wanted me to know, she would have told me- and her own wishes still matter to me. To Tamara (and to Barbara Settles), those kind words in my behalf are among life's debts I can never repay.

We now come to the historically tragic date of 9-11 and its aftermath for Tamara. The University of Delaware is located almost equidistant between Washington, D.C., and New York City. The university student body, including our own graduate program, included many students from both Washington and the Big Apple. When the terrorist strikes hit the Pentagon in D.C. and the Twin Towers in New York on 11 September 2001, shock waves rolled through campus. At some point during the day, Tamara called me and asked me to come to her office. She was not doing well. She told me she could not bear to be alone on the evening of such a tragedy. I called my wife Sandra and the two of us went to dinner with her. None of us knew what to say but the comfort of being together was something. I must interject that in the 1970s and 80s, Tamara developed some cutting-edge research methodologies for family history. The Church of Jesus Christ of Latter-day Saints flew Tamara to Salt Lake City, Utah, so she could teach leading family history experts in our church about her tools, methods, and concepts. So, [back to our 9-11 dinner] we are sitting there in the aftermath of this horrifying travesty and Tamara (who had polished off a couple of glasses of wine by this point) says, "LAH-ren, it is true that you were a Mormon missionary?"

"Yes, I was".

"And who paid for your mission-your church?" she asked.

"No, my family and I did".

Rarely shy with her opinions, she rebutted, "I do not like this. Asking so much of one so young. Allowances should be made for the life course. Ask more of the old, less of the young". Then, Tamara, smiled and said, "You know about my trip to Utah? Well, you were a volunteer Mormon missionary but I, I was a missionary TO the Mormons ... . And I got paid ... handsomely". A wry smile followed, punctuated by a celebratory sip of wine as her champagne of victory. Even in a dark hour, Tamara retained her quintessentially Jewish ability to banter and quip. I suspect that she had been formulating this playful jab for months, but whether calculated or spontaneous, it was beautifully executed.

Shortly after 9-11, I took Tamara to the Philly airport on what (I believe) was her last international journey of this life. Typically, I dropped her off at the curbside but on this occasion, her typical phobias seemed to be at record levels. "LAH-ren, please come in with me this time", she pleaded.

I was not particularly happy to have driven in thick I-95 traffic to begin with and I knew that parking in a distant garage and then running from the parking garage back to the curb was likely going to cost me the ball game I was hoping to play in that night, but I 
honored her request. Regrettably, it was not out of love-I was still enroute to fulfilling the quest to love her. Honestly, I think I agreed because I was stunned by the anomalous oddity of her request in several respects. First, she had never asked me to go into the airport with her before. Second, she rarely "asked" me to do anything-she typically gave orders. Third, she had almost never said please to me-and her 'please' pierced me.

So, I dropped her at the curb because her walking was heavily labored at this stage of her life. I headed for the distance in the feeble hope of finding a free parking place during peak hours. It took me perhaps 10-15 min to park and jog back to the curb where I had dropped her off. She had not gone inside the terminal and was shaking and trembling badly. As we stepped inside the terminal with me steadying her, I saw that the post-terrorist attack protocols for security included a heavy array of military personnel in fatigues, many carrying assault rifles. Tamara suddenly grabbed and clung to me in a manner reminiscent of my little daughter's desperate death cling to me during swimming lessons when she was still terrified of the water. Tamara grasped me for an awkwardly long period of time and then said, "I need a drink".

We found an airport lounge and entered it. It was my first trip to a bar. She ordered one drink, then two, not speaking and entirely lost in her thoughts. I was profoundly perplexed by all of this but had the impression that silence was best. Finally, near the end of her final drink, she seemed to partially emerge from her far-off place and managed to say, "I am sorry for this LAH-ren. You see, when I saw all the men with the rifles, it reminded me of when I was a little girl in the concentration camp".

I have rarely felt the earth shake under me, but it did then. In my years of combined servitude and friendship with Tamara, I had not known that she had been in a Nazi concentration camp as a child-I was entirely unaware that she was a bona fide Holocaust survivor.

The one-hour drive back home was a time of revisiting everything I thought I knew and understood about Tamara Hareven. I reconsidered her frequent aloofness, her often "prickly" interaction style, her firmly enforced distance from emotional expression, and her desire for firm, unquestioned control. I reflected again and again on the consensus view in psychology that "During the first six years, the template for later life is set down" (Doherty 2000, p. 43). At this time of the Holocaust revelation from Tamara, our oldest daughter Mishonne was almost four years old and the thought of her experiencing the emotional, physical, and spiritual pain Tamara did, was almost too much for me to contemplate. I experienced what the philosopher of science Thomas Kuhn would call a paradigm shift or what some sacred texts refer to as "a mighty change of heart". With my newly broken heart, I discovered that I had finally come to love Tamara Hareven.

We never spoke of this shared experience again. I will say that when Tamara's next phone call requesting prayer rang soon thereafter in the dark hours of night, I prayed with her in a different way-with a kind of Jewish pain and yearning that had never been there before. Twenty years later, that pain and yearning have not left.

In summer 2002, it was time to pack up my family. Sandra and I had three children now and were leaving for LSU. I went to say goodbye to Tamara at her upstairs apartment. She was quite formal and pragmatic, almost guarded, as she offered counsel on how to weather my first job in academia, a job she had been instrumental in helping me land. I left feeling a little empty after a brisk handshake and headed down the stairs toward my car one block away. As I neared my car, I heard a loud cry, "LAH-ren!!" I looked back in surprise to see that Tamara had descended from her apartment and was hurrying desperately towards me with great effort. For the first and only time, she embraced me. She would leave this life three months later.

\section{Conclusions}

As powerful as her research and writing was, Tamara Hareven's own story will always be what moves me most. It is the story of a little Jewish girl who survived a Nazi concentration camp, and in spite of the life-long scars left by that experience would climb 
to become an international leader in both new social history and family history—one of sufficient gravitas to garner bi-coastal obituaries (in the New York Times and Los Angeles Times). She was a woman who knew considerable fears, challenges, and limitations but stubbornly refused to allow any of these stymie her. Tamara was, to borrow her own phrase, a hero of her own life.

In her passing, Tamara bequeathed two things to me. First, she gave me an original watercolor that brought her joy (and graces my office wall at Brigham Young University). Second, she left me a hardbound copy of Chaim Potok's The Book of Lights. The book contains a passage from the Jewish Zohar that I have come to cherish:

A wise man knows for himself as much as is required, but the [person] of [true] discernment apprehends the whole, knowing both his own point of view and that of others .... He apprehends the lower world and the upper world, his own being and the being of others. (p. 336)

Tamara Hareven was a demanding, often exasperating woman who mentored, molded, and scolded me. She will ever be my academic mother and her voice remains inside me, urging me to be stronger, better, more careful, and more wise than I am.

As I did at her memorial twenty years ago, I close by offering a final prayer for her:

Numbers 6:24-26

The LORD bless you and protect you!

The LORD deal kindly and graciously with you!

The LORD bestow His favor upon you and grant you peace!

Shalom, Tamara.

Funding: This research received no external funding.

Conflicts of Interest: The author declares no conflict of interest.

\section{Notes}

1 I also largely credit the fine interviewing work of Kathleen Adams, Hareven's long-time collaborator.

2 As this article went through the peer review process, one reviewer offered the following insights that I appreciated and have elected to include to offer richer perspective: "As to her person, Tamara had an excellent intuition of people and ... opportunities, that helped her to decide instantly. Also, Tamara was in daily control, as far as possible long distance, of the situation of her hospitalized mother, and would make sure every doctor and nurse knew her eyes were on them. It was, in a way, a paradox that she was so far away. As to her academic career, her being for a long period the chair of the SSHA Family network-at a time when the European SSHA did not yet exist, so many European scholars went to the USA-and her being very welcoming to young scholars, placed her in a central position among family historians".

3 In recent years, "Mormons" prefer to be called "members of the Church of Jesus Christ of Latter-day Saints" but "Mormon" was the common term of the time and no disrespect was intended.

4 Delaware administrators did not typically place Tamara on department committees. Instead, much of her university service was as a liaison who brought high profile international scholars to the University of Delaware campus to speak. She was effective and valuable in doing so and included me in the touring and dining activities of these scholars. Some of the European academic sensibilities of her colleagues, that Tamara also manifested, permanently affected me. Two concepts that have had lasting influence on me include: (a) a frustration with the cultural myopia that too often prevails in the American academy-a tendency I sought to actively combat in myself by chairing (and learning much from) doctoral students from China, Ukraine, Romania, Nigeria, and Saudi Arabia; and (b) an aversion to the prevalent American idea that hiring a PhD onto the faculty of the alma mater is tantamount to "inbreeding". By contrast, a European idea and practice is to hire the very best from a university's own program - to reap the harvest of several years of investment by retaining individuals who have proven themselves exceptional. This approach makes a great deal of sense to me, but I have been able to find no traction for it here in the U.S.

5 Jewish Publication Society Tanakh Translation.

\section{References}

Buck, Pearl S. 1931. The Good Earth. New York: Barnes \& Noble.

Doherty, William J. 2000. Take Back Your Kids. Notre Dame: Sorin.

Elder, Glen H., and Tamara K. Hareven. 1994. Rising above life's disadvantage: From the Great Depression to the war. In Children in Time and Place: Developmental and Historical Insights. Edited by Glen H. Elder, John Modell and Ross D. Parke. Cambridge: Cambridge University Press, pp. 47-70. 
Eliot, George. 1871. Middlemarch. New York: Penguin.

Hareven, Tamara K., ed. 1978a. Transitions: The Family and the Life Course in Historical Perspective. Cambridge, MA: Academic.

Hareven, Tamara K. 1978b. Amoskeag: Life and Work in an American Factory-City. Hanover: New England Press.

Hareven, Tamara K. 2000. Families, History and Social Change: Life Course and Cross-Cultural Perspectives. Boulder: Westview Press.

Hareven, Tamara K. 2002. Silk Weavers of Kyoto: Family and Work in a Changing Traditional Industry. Berkeley: University of California Press.

Marks, Loren D. 2015. A pragmatic, step-by-step guide for qualitative methods. Current Psychology 34: 494-505. [CrossRef]

Marks, Loren D., and David C. Dollahite. 2017. Religion and Families. New York: Routledge.

Potok, Chaim. 1981. The Book of Lights. New York: Fawcett.

Settles, Barbara. 2003. In Memoriam-Tamara K. Hareven. Available online: http://www1.udel.edu/PR/UDaily/01-02/thareven.html (accessed on 10 August 2021).

Wall, Richard, Tamara K. Hareven, Josef Ehmer, and M. Cerman, eds. 2001. Family History Revisited. Newark, DE: University of Delaware Press. 